\title{
Perancangan Enterprise Architecture UNIPAS Morotai Menggunakan TOGAF ADM
}

\author{
Faisal Thaib $^{1 *}$, Andi Wahju Rahardjo Emanuel ${ }^{2}$ \\ ${ }^{1,2}$ Program Studi Teknik Informatika, Universitas Atmajaya Yogyakarta, DI Yogyakarta \\ Email: ${ }^{1 *}$ faisalthaib2019@gmail.com, ${ }^{2}$ andi.emanuel@uajy.ac.id
}

(Naskah masuk: 30 Jan 2020, direvisi: 16 Mar 2020, diterima: 24 Mar 2020)

\begin{abstract}
Abstrak
Dalam menciptakan keselarasan dan sinergitas bisnis dengan teknologi informasi untuk kebutuhan organisasi merupakan salah satu tujuan untuk pengembangan organisasi. Penerapan model Enterprise Architecture (EA) pada organisasi adalah untuk membuat perencanaan, perancangan dan strategi arsitektur bisnis organisasi. Model Enterprise Architecture (EA) sangat penting diterapkan pada organisasi/perusahan karena prosesnya berlanjut hingga pada tahapan implementasi. Oleh karena itu dalam penelitian ini, penulis akan membuat perancangan arsitektur enterprise teknologi informasi (TI) pada salah satu lembaga Pendidikan Tinggi di Provinsi Maluku Utara, Universitas Pasifik (UNIPAS) Morotai, untuk dapat meningkatkan kualitas pelayanan kepada pihak-pihak yang berkepentingan. Dalam penelitian ini akan menggunakan pendekatan metode TOGAF ADM. Kerangka kerja arsitektur ini dapat dijadikan sebagai metode atau acuan oleh Perguruan Tinggi (PT) dalam membuat perancangan Enterprise Architecture (EA), untuk menghasilkan sebuah cetak biru (blue print) arsitektur sistem informasi dengan berdasarkan prioritas kebutuhan organisasi, sehingga dalam proses implementasi lebih terukur dan sistematis untuk mencapai tujuan strategis organisasi.
\end{abstract}

Kata Kunci: Perancangan, Enterprise Architecture, Sistem Informasi, TOGAF ADM, UNIPAS Morotai.

\section{Enterprise Architecture Design of UNIPAS Morotai Using TOGAF ADM}

\begin{abstract}
In creating business harmony and synergy with information technology for organizational needs is one of the goals for organizational development. The application of the Enterprise Architecture (EA) model in organizations is to make the planning, design, and strategy of an organization's business architecture. Enterprise Architecture Model (EA) is very important to be applied to organizations/companies because the process continues to the implementation stage. Therefore, in this study, the author will design an information technology enterprise (IT) architecture at one of the Higher Education institutions in North Maluku Province, Pacific University (UNIPAS) Morotai, to be able to improve the quality of service to interested parties. This research will use the TOGAF ADM method approach. This architectural framework can be used as a method or reference by universities in making the design of Enterprise Architecture (EA), to produce a blueprint for information systems architecture based on the priority needs of the organization, so that the implementation process is more measurable and systematic to achieve the organization's strategic objectives.
\end{abstract}

Keywords: Design, Enterprise Architecture, Information System, TOGAF ADM, UNIPAS Morotai. 


\section{PENDAHULUAN}

Setiap organisasi memiliki sistem tata kelola atau domain bisnis yang berbeda-beda, sehingga visi/misi, tujuan, dan strategi organisasi yang dirumuskan pun tentu berbeda antara organisasi yang satu dengan yang lainnya. Dalam menjalankan proses bisnis untuk pengembangan organisasi di era digital saat ini, organisasi membutuhkan arsitektur sistem informasi serta proses data yang cepat dan terukur untuk mendukung pengembangan bisnis organisasi.

Salah satu faktor yang mendorong organisasi untuk menerapkan sistem Enterprise Architecture (EA) adalah karena semakin meningkatnya kebutuhan organisasi. Dengan kondisi demikian organisasipun akan mengalami masalah dalam proses bisnis yang dijalankannya, organisasi akan kesulitan dan dilema untuk menentukan metode yang tepat dalam penerapan arsitektur bisnis berdasarkan kebutuhan organisasi, karena banyak pilihan metode atau kerangka (framework) yang dapat digunakan sebagai metode untuk membuat keselarasan strategi bisnis dengan teknologi informasi (TI) dalam mencapai tujuan strategis organisasi. Untuk menjawab masalah atau tantangan yang dihadapi, maka organisasi harus menerapkan arsitektur enterprise yang menyediakan suatu kerangka perencanaan agar dapat membuat keputusan TI ke depan yang tepat dan jelas, dengan mempertimbangkan kebutuhan organisasi.

Arsitektur Enterprise merupakan alat (tools) yang dapat digunakan untuk membangun sinergitas dan keselarasan antara TI dengan bisnis organisasi [1]. Sinergitas dan keselarasan bisa dicapai jika organisasi mampu mendefinisikan internal kebutuhannya, dimulai dari bagaimana mendefinisikan arsitektur bisnis, data, aplikasi, dan arsitektur teknologi yang dapat mendukung jalannya proses bisnis sebuah organisasi. Pada setiap tahapan dan proses untuk perancangan arsitektur enterprise perlu memperhatikan domain bisnis dari organisasi, domain informasi, data, dan teknologi.

Lembaga Pendidikan Tinggi memiliki domain bisnis yang berbeda dengan domain bisnis pada organisasi lainnya. Khususnya di Indonesia, ada dua jenis lembaga Pendidikan Tinggi di Indonesia yaitu Perguruan Tinggi Negeri (PTN) dan Perguruan Tinggi Swasta (PTS). Dua jenis lembaga pendidikan tinggi ini memiliki domain bisnis yang sama, akan tetapi yang membedakan dari keduanya adalah bagaimana strategi dan manajemen dari perguruan tinggi masing-masing, jika semakin berkembang dan majunya Perguruan Tinggi maka semakin besar juga kebutuhannya. Lembaga pendidikan tinggi adalah organisasi yang lebih mengarahkan perannya untuk bersentuhan langsung dengan teknologi informasi (TI) dalam mendukung proses kegiatan Akademik, baik dari aspek operasional, manajemen, keuangan, dan yang lainnya, maka perlu adanya keselarasan untuk tercapainya investasi teknologi berdasarkan kebutuhan bisnis Perguruan Tinggi [2].

Oleh karena itu dalam penelitian ini, penulis akan membuat perancangan arsitektur enterprise teknologi informasi (TI) pada salah satu lembaga Pendidikan Tinggi di Provinsi Maluku Utara yaitu Universitas Pasifik (UNIPAS)
Morotai, karena berdasarkan hasil penelitian dan data yang dihimpun oleh penulis, bahwa pemanfaatan teknologi informasi di UNIPAS Morotai masih belum tertata dan tumpang tindih, atau kurang optimal, sehingga penulis akan membuat perancangan arsitektur bisnis dan sistem informasi yang terintegrasi, dengan pendekatan metode TOGAF ADM dengan proses dan tahapan yang dapat menghasilkan sebuah Enterprise Architecture (EA) secara baik dan benar dalam mencapai visi dan tujuan strategis organisasi. Perancangan arsitektur enterprise ini akan menghasilkan cetak biru (blueprint) sebagai acuan/panduan untuk membangun sinergitas dan keselarasan antara sistem informasi dengan fungsi bisnis organisasi.

\section{LANDASAN TEORI}

\section{A. Arsitektur Enterprise}

Enterprise Architecture (EA) atau biasa dikenal dengan arsitektur enterprise adalah deskripsi dari misi seluruh stakeholder yang di dalamnya terdiri dari informasi, fungsi/kegunaan, arah organisasi, dan parameter kinerja arsitektur enterprise dalam menggambarkan perancangan atau rencana dan mengembangkan sebuah sistem yang dapat terintegrasi [3].

Dalam penerapan arsitektur enterprise, organisasi harus menggunakan suatu framework yang sering digunakan sebagai metode untuk melakukan suatu pengembangan arsitektur enterprise. Karena dengan adanya metode, maka organisasi bisa mengelola suatu sistem yang kompleks serta dapat menyelaraskan tujuan bisnis dan teknologi informasi (TI) yang akan di investasikan [4][5].

\section{B. TOGAF ADM}

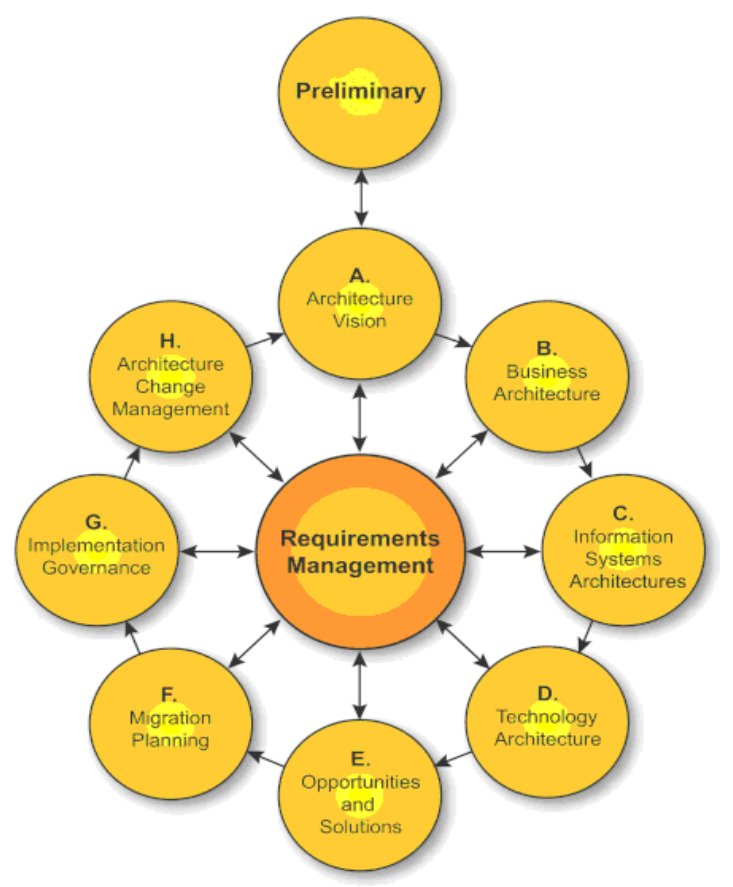

Gambar 1. TOGAF ADM 
TOGAF adalah kerangka (framework) atau metode untuk mengembangkan Enterprise Architecture (EA), yang berawal dari Teknis Arsitektur untuk Manajemen Informasi (TAFIM) di Departemen Pertahanan, Amerika Serikat (AS), yang diadopsi oleh Open Group pada tahun 1990, dan TOGAF ADM awalnya diperkenalkan pada tahun 1995, dimulai dari TOGAF 8 (delapan) yang dirilis pada tahun 2004 dan saat ini versi terbaru adalah TOGAF 9.2 dimana pada versi ini telah dilengkapi pengembangan dari versi sebelumnya [6].

TOGAF telah menyediakan metode secara lengkap tentang mekanisme membangun, mengelola, dan implementasi Enterprise Architecture (EA) sistem informasi dengan metode pengembangan arsitektur ADM. ADM merupakan bagian dari hasil kolaborasi para pelaksana arsitektur di Open Group Architecture Forum. ADM sebagai metode dengan memiliki aktivitas yang dapat digunakan untuk memodelkan pengembangan bisnis, serta dapat dijadikan sebagai acuan dalam membuat perencanaan, perancangan, pengembangan, dan mengimplementasikan arsitektur sistem informasi pada suatu organisasi [7][8][9].

Kerangka sistem dibuat dengan berdasarkan kebutuhan dalam proses bisnis, serta bagaimana mengimplementasikan. Dalam penerapan Enterprise Architecture (EA) dengan pendekatan TOGAF ADM tentu memiliki beberapa proses atau aktivitas yang akan memberikan pemahaman yang lebih konkrit dan jelas tentang bagaimana melakukan perencanaan dan perancangan model arsitektur enterprise [10]. Model Enterprise Architecture (EA) merupakan kerangka dasar yang dapat digunakan sebagai perancangan dan perencanaan teknologi informasi (TI), yang terintegrasi untuk mencapai tujuan strategis organisasi [11]. TOGAF ADM sebagai metode yang mudah untuk diimplementasikan berdasarkan kebutuhan organisasi, baik itu organisasi industri, manufaktur, dan akademik seperti lembaga pendidikan tinggi (kampus) [3][12].

Menurut David L Cohn, bahwa perusahaan seharusnya mudah memodifikasi dan mengadaptasi proses bisnis dalam mempertahankan keunggulan kompetitif perusahan, integrasi proses bisnis, dan manajemen merupakan kunci untuk mengelola dan membangun infrastruktur e-bisnis adaptif [13]. Gavin menjelaskan bahwa perubahan strategi teknologi informasi (TI) dilakukan di CERN sebagai langkah mengantisipasi berbagai strategi organisasi, sehingga pada akhirnya pihak manajemen memutuskan untuk menggunakan teknologi informasi dan komputasi awan sebagai infrastruktur teknologi informasi pada pusat data [14].

Tujuan penelitian ini adalah untuk membuat perancangan (design) arsitektur enterprise berupa cetak biru, berdasarkan proses atau tahapan arsitektur yang direkomendasikan agar dapat mendukung jalannya proses bisnis di UNIPAS Morotai.

\section{METODE PENELITIAN}

Dalam penelitian ini, akan dibuat rencana induk atau cetak biru (blueprint) Enterprise Architecture (EA) terhadap layanan proses bisnis di Universitas Pasifik (UNIPAS) Morotai untuk mendukung implementasi TI. Pendekatan penelitian ini dilakukan atas kondisi dan masalah yang dihadapi dalam proses akademik di Universitas Pasifik (UNIPAS) Morotai. Berdasarkan data yang dihimpun melalui observasi dan wawancara dengan para pemangku kepentingan, maka akan dilakukan proses pemodelan Enterprise Architecture (EA) dengan metode kerangka (framework) TOGAF ADM. Namun dalam penelitian ini penulis hanya menggunakan 4 (empat) proses atau tahapan perancangan arsitektur dari 8 (delapan) proses arsitektur yang direkomendasikan oleh framework TOGAF ADM. Adapun metodologi utama yang digunakan dalam penelitian ini adalah sebagaimana pada Gambar 2 di bawah ini.

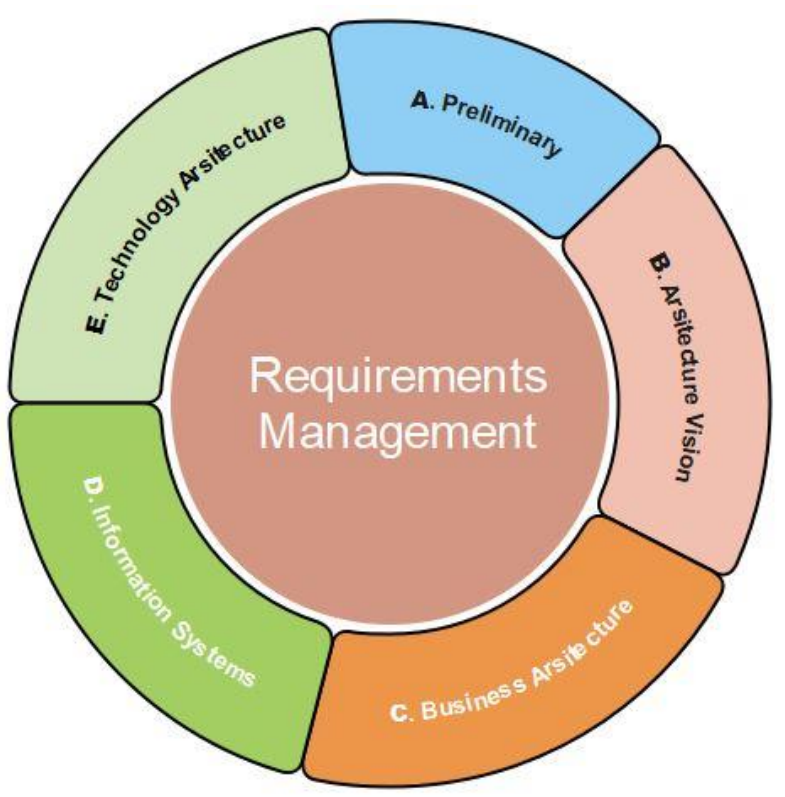

Gambar 2. Metodologi Penelitian

\section{A. Preliminary}

Pada tahapan ini merupakan tahapan untuk mengidentifikasi kondisi serta proses-proses bisnis yang berhubungan dengan sistem atau aktivitas utama pada Universitas Pasifik (UNIPAS) Morotai, yang akan dipetakan dengan menggunakan rantai nilai (value chain).

\section{B. Architecture Vision}

Dalam menciptakan keseragaman pandangan tentang pentingnya membangun arsitektur enterprise untuk mencapai tujuan strategis organisasi, yang akan dipetakan dalam bentuk strategi dan menentukan ruang lingkup dari arsitektur yang nantinya dikembangkan. Dalam tahapan ini juga akan dibahas tentang visi dari desain Enterprise Architecture (EA) yang dilakukan untuk mendukung proses dari aktivitas bisnis berdasarkan visi dan misi organisasi. 


\section{Business Architecture}

Pada tahapan ini, merupakan tahap analisis terhadap proses bisnis organisasi yang sedang berjalan.

\section{Information System Architecture}

Pada tahapan ini, akan dilakukan proses pemodelan arsitektur atau rancangan sistem informasi (SI) yang sesuai dengan hasil rancangan sebelumnya, meliputi model arsitektur aplikasi dan arsitektur data serta proses arsitektur.

\section{HASIL DAN PEMBAHASAN}

Pemodelan Enterprise Architecture (EA) dengan menggunakan pendekatan kerangka kerja TOGAF, yang dapat mendukung sistem informasi dalam menjalankan Proses Akademik di Universitas Pasifik (UNIPAS) Morotai berdasarkan tahapan proses arsitektur. Proses akan dilakukan dengan model arsitektur enterprise melalui tahapan TOGAF ADM.

\section{A. Preliminary}

Pada tahapan ini, penulis akan menggambarkan ruang lingkup dan kondisi eksisting di Universitas Pasifik (UNIPAS) Morotai. UNIPAS Morotai merupakan satu dari sekian Perguruan Tinggi Swasta (PTS) yang ada di Propinsi Maluku Utara yang didirikan pada tahun 2013, berdasarkan keputusan Menteri Pendidikan No. 08/E/O/2013 tentang izin pendirian Universitas Pasifik (UNIPAS) Morotai dibawah naungan Yayasan Perguruan Morotai, yang terdiri dari 6 (enam) Fakultas dan 11 (sebelas) program studi. Untuk mengimplementasikan amanat UU Perguruan Tinggi (PT), maka Universitas Pasifik (UNIPAS) Morotai memiliki kewajiban untuk melaksanakan pendidikan, penelitian, dan pengabdian kepada masyarakat (Tridharma Perguruan Tinggi), serta berperan aktif dalam mengembangkan ilmu pengetahuan, teknologi dan seni untuk ikut bertangung jawab mencerdaskan kehidupan bangsa, khususnya di daerah perbatasan untuk mengatasi berbagai problem demi meningkatkan kesejahteraan masyarakat [15].

Berdasarkan data yang dihimpun oleh penulis melalui wawancara dengan para pemangku kepentingan universitas dalam hal ini pimpinan, Rektor, Pembantu Rektor I, Pembantu Rektor II, Pembantu Rektor III, serta para kepalakepala bagian/unit seperti, Kepala Biro Akademik, Biro Umum, Biro Keuangan dan Operator IT, bahwa terdapat beberapa permasalahan yang dihadapi dalam proses pengelolaan akademik, baik dalam sistem pemrosesan data organisasi dan penyajian informasi. Hal ini disebabkan karena lemahnya pemanfaatan teknologi yang tidak efektif, serta tidak ada sistem terintegrasi yang dibangun untuk mendukung kegiatan proses akademik. Sistem manajemen pengelolaan akademik (SDM, keuangan, aset dan fasilitas) juga masih menggunakan sistem komputerisasi dengan aplikasi pengolahan data yang sederhana seperti Microsoft Office dan Excel yang tidak berlisensi. Sistem manajemen yang saat ini digunakan tentu belum sepenuhnya memenuhi tuntutan tata kelola universitas yang baik (good university management).

Dari hasil identifikasi penulis, bahwa masalah utamanya adalah karena Universitas Pasifik (UNIPAS) Morotai merupakan universitas baru, serta kurangnya perhatian dan pemahaman para pemangku kepentingan tentang pentingnya peran teknologi informasi dalam proses pengelolaan dan pengembangan organisasi. Oleh karena itu sangat dibutuhkan perancangan arsitektur enterprise teknologi informasi (TI) untuk mendukung tata kelola dalam mencapai visi dan tujuan strategis organisasi, sebagaimana yang diharapkan oleh para pemangku kepentingan berdasarkan kategori kerangka (framework) penerapan arsitektur yang direkomendasikan.

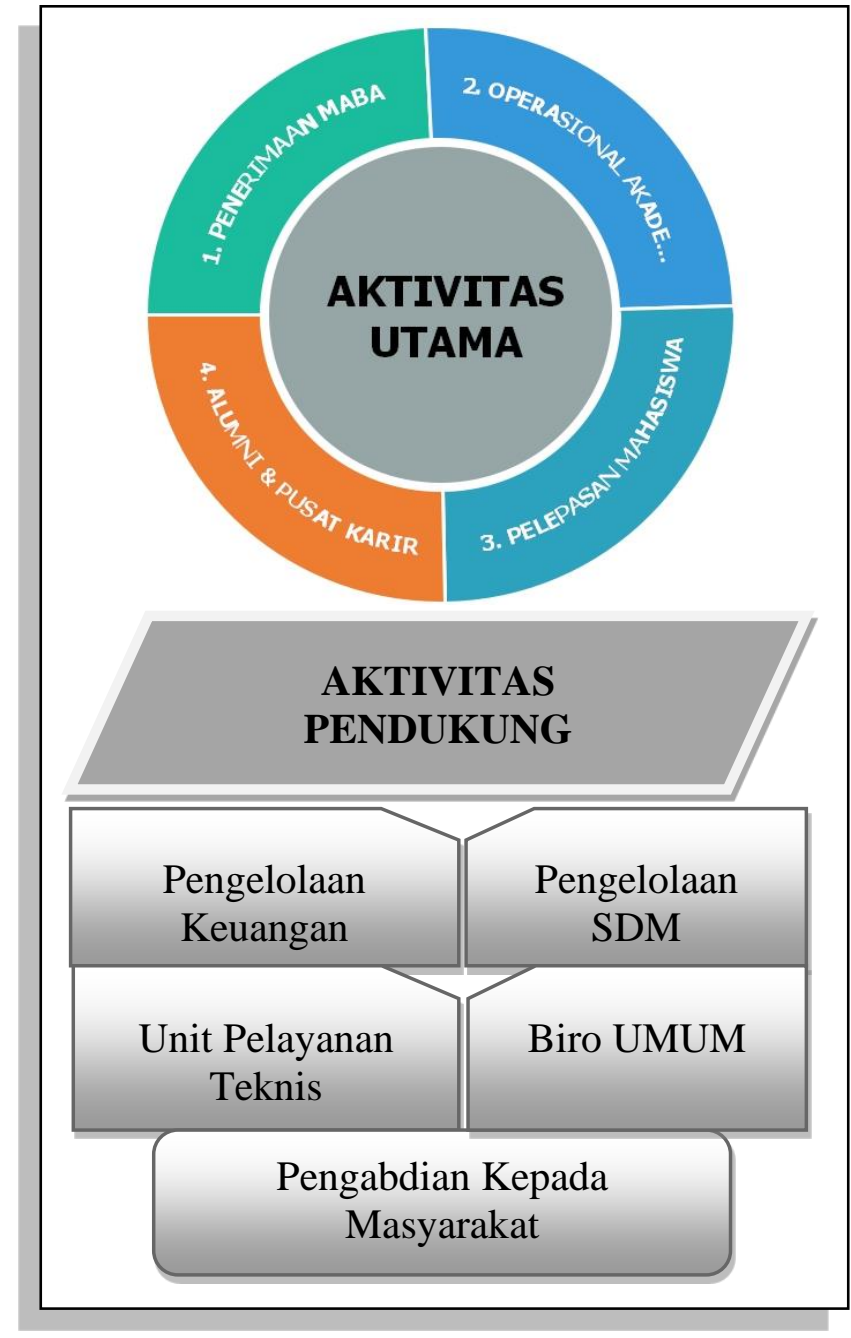

Gambar 3. Rantai Nilai UNIPAS Morotai

1. Aktivitas utama yang terdiri dari:

a) PMB, merupakan kegiatan akademik, yang mengatur tentang proses penerimaan, tes masuk, hingga pada proses pendataan mahasiswa baru.

b) Operasional Akademik, merupakan proses akademik tentang pengolahan proses perkuliahan, kurikulum, tugas akhir, ujian, pengelolaan nilai, transkip nilai, serta pengelolaan beasiswa dari berbagai sumber. 
c) Pelepasan, merupakan sebuah proses akademik yang berhubungan dengan manajemen akhir studi mahasiswa, melalui pendaftaran tugas akhir.

d) Alumni, merupakan aktivitas pendataan lulusan/alumni (Tracer Study), yang meliputi pendataan tempat kerja, jabatan, serta menyediakan media informasi alumni untuk membantu para alumni dalam pencarian kerja.

2. Aktivitas pendukung yang terdiri dari:

a) Pengelolaan Keuangan, merupakan proses pengelolaan dan menejemen keuangan universitas.

b) Unit Pelayanan Teknis, merupakan proses aktivitas pengelolaan IT dalam proses kegiatan pendidikan serta pengelolaan unit laboratorium dan perpustakaan.

c) Pengelolaan SDM, merupakan aktivitas untuk memastikan alokasi sumber daya manusia (SDM) terhadap proses akademik, yang berhubungan dengan pengelolaan staf dan dosen.

d) Pengabdian Kepada Masyarakat, merupakan proses aktivitas pengelolaan akademik tentang pengabdian, pelatihan dan penelitian, baik secara individu maupun kelompok.

e) Biro Umum, merupakan aktivitas dalam proses memastikan kebutuhan sarana dan prasarana universitas, yang meliputi ketersediaan ruang, manajemen asset, serta kesiapan perlengkapan proses perkuliahan akademik.

\section{B. Vision Architecture}

Pada tahap ini, dimana fase arsitektur akan mengambarkan perencanaan arsitektur enterprise untuk memenuhi tujuan strategis organisasi, sehingga para pemangku kepentingan mempunyai perhatian yang besar selama proses implementasi. Visi arsitektur merupakan instrumen yang sangat dibutuhkan dalam menginformasikan konsep arsitektur teknologi informasi (TI) kepada pemangku kepentingan, untuk membuat keputusan dalam mengatur rencana strategis bisnis pada UNIPAS Morotai sebagaimana yang direkomendasikan dalam fase persiapan, sehingga dapat menghasilkan perancangan arsitektur sesuai yang diharapkan.

\section{Business Architecture}

1. Proses PMB

Proses penerimaan mahasiswa baru (PMB) merupakan proses yang berfokus terhadap pengelolaan penerimaan mahasiswa baru, mulai dari perencanaan Penerimaan, Promosi, hingga pada tahapan pendaftaran (registrasi). Pengelompokan aktifitas-aktifitas dari PMB dapat dilihat pada Tabel 1.

Tabel 1. Proses Arsitektur PMB

\begin{tabular}{ccc}
\hline No & Sub Proses & \multicolumn{1}{c}{ Aktivitas } \\
\hline 1 & Kebijakan & - Penetapan Kalender \\
& Akademik & Akademik \\
& & - Penetapan Pengajar \\
& & - Jadwal Mengajar \\
& & - Perwalian Pengajar \\
\hline
\end{tabular}

\begin{tabular}{|c|c|c|}
\hline & & $\begin{array}{l}\text { - Pengelolaan Rencana Studi } \\
\text { - Perubahan Rencana Studi } \\
\text { - Cuti Akademik }\end{array}$ \\
\hline 2 & Belajar/Mengajar & $\begin{array}{l}\text { - Pengawasan dan Evaluasi, } \\
\text { - Data Dosen } \\
\text { - Data Mahasiswa } \\
\text { - Panitia Ujian } \\
\text { - Pelaksanaan Ujian } \\
\text { - Administrasi Nilai } \\
\text { - Transkrip } \\
\text { - Pelaporan Akademik } \\
\text { - Kerja Praktek } \\
\text { - Sidang KP }\end{array}$ \\
\hline 3 & Akhir Studi & $\begin{array}{l}\text { - Seminar Tugas Akhir } \\
\text { - Jadwal Pelaksanaan Seminar } \\
\text { - Sidang Tugas Akhir }\end{array}$ \\
\hline
\end{tabular}

2. Proses Operasional Akademik

Proses operasional akademik merupakan proses yang berfokus pada pengelolaan pelaksanaan pendidikan, dimana proses ini adalah aktivitas utama pada Perguruan Tinggi khusunya pada Universitas Pasifik (UNIPAS) Morotai. Proses penyelenggaran pendidikan akan ditangani oleh bagian Biro Adminstrasi Akademik (BAAKAPSI). Pengelompokan proses aktivitas-aktivitas operasional akademik dapat dilihat pada Tabel 2 .

Tabel 2. Proses Operasional Akademik

\begin{tabular}{lll}
\hline No & Sub Proses & \multicolumn{1}{c}{ Aktivitas } \\
\hline 1 & Kebijakan & - Penetapan Kalender \\
& Akademik & Akademik \\
& & - Penetapan pengajar \\
& & - Jadwal Mengajar \\
& & - Perwalian Pengajar \\
& & - Pengelolaan Rencana Studi \\
& & - Perubahan rencana Studi \\
& & - Cuti Akademik \\
\hline 2 & Belajar/Mengajar & - Pengawasan dan Evaluasi, \\
& & - Data Dosen \\
& & - Data Mahasiswa \\
& & - Panitia Ujian \\
& & - Pelaksanaan Ujian \\
& & - Administrasi Nilai \\
& & - Transkrip \\
& & - Pelaporan Akademik \\
& & - Sidang KP \\
\hline 3 & Akhir Studi & - Seminar Tugas Akhir \\
& & - Jadwal Pelaksanaan Seminar \\
& & - Sidang Tugas Akhir \\
\hline
\end{tabular}

3. Pelepasan Mahasiswa

Proses pelepasan mahasiswa merupakan proses pengelolaan akhir aktivitas mahasiswa dalam studi akademik di Perguruan Tinggi. Pengelompokan atau proses aktivitasaktivitas untuk pelepasan mahasiswa dapat dilihat pada Tabel 3. 
Tabel 3. Proses Pelepasan Mahasiswa

\begin{tabular}{cccc}
\hline No & Sub Proses & \multicolumn{1}{c}{ Aktivitas } \\
\hline 1 & Pelepasan & - & Perencanaan Pelaksanaan Wisuda \\
& & - & Pembentukan Panitia \\
& & - & Pelaksanaan Wisuda \\
& & Penetapan Kelulusan \\
& & Evaluasi Kegiatan Wisuda \\
& & - Pembuatan Ijazah dan Transkrip \\
& & Perubahan Status Mahasiswa \\
\hline
\end{tabular}

4. Alumni dan Pusat Karir

Pada tahapan ini merupakan proses pengelolaan pendataan lulusan dan/atau alumni, dimulai dari pendataan tempat bekerja, masa bekerja, jabatan, serta menyediakan media informasi lowongan kerja alumni. Adapun pengelompokan proses aktivitas alumni dan pusat karir dapat dilihat pada Tabel 4.

Tabel 4. Proses Alumni dan Pusat Karir

\begin{tabular}{|c|c|c|}
\hline No & Sub Proses & Aktivitas \\
\hline 1 & $\begin{array}{l}\text { Pendataan } \\
\text { Alumni dan } \\
\text { Pusat karir }\end{array}$ & $\begin{array}{l}\text { - Pembentukan Komite } \\
\text { - Pendataan Biodata Alumni } \\
\text { - Pendataan, Tempat Kerja (lokasi) } \\
\text { dan, jabatan dan masa kerja }\end{array}$ \\
\hline 2 & $\begin{array}{l}\text { Pengumuman } \\
\text { Lowongan } \\
\text { Pekerjaan }\end{array}$ & $\begin{array}{lll}\text { - Pengelolaa data lowongan } \\
\text { pekerjaan } \\
\text { - Memberikan informasi lowongan } \\
\text { pekerjaan }\end{array}$ \\
\hline
\end{tabular}

\section{Information Systems Architecture}

Pada tahapan ini akan dikelompokan menjadi 2 (dua) fase yaitu, tahapan model arsitektur data dan arsitektur aplikasi. Pada tahapan implementasinya bukan berarti bahwa arsitektur data yang menjadi fokus utama, kemudian dilanjutkan dengan arsitektur aplikasi, akan tetapi dapat dilakukan sebaliknya.

\section{Data}

Dari hasil pengamatan dan identifikasi pada proses utama atau proses kegiatan akademik di Universitas Pasifik (UNIPAS) Morotai, maka perlu dilakukan identifikasi data sebagai instrumen yang digunakan dalam proses perancangan arsitektur untuk mendukung proses bisnis Universitas Pasifik (UNIPAS) Morotai. Adapun pengelompokan data dapat dilihat pada Tabel 5.

Tabel 5. Arsitektur Data

\begin{tabular}{cccl}
\hline No & Sub Proses & \multicolumn{1}{c}{ Aktivitas } \\
\hline 1 & Pelepasan & - & Perencanaan Pelaksanaan Wisuda \\
& & - & Pembentukan Panitia \\
& & - & Pelaksanaan Wisuda \\
& & Penetapan Kelulusan \\
& & Evaluasi Kegiatan Wisuda \\
& & - & Pembuatan Ijazah dan Transkrip \\
& &
\end{tabular}

\section{Arsitektur Aplikasi}

Untuk mewujudkan sinergitas sistem informasi dan bisnis organisasi, maka diperlukan perencanaan sistem informasi (SI) dan aplikasi yang dibutuhkan dalam mendukung proses bisnis di UNIPAS Morotai. Adapun rencana sistem informasi dan aplikasi yang akan dibangun dapat dilihat pada Tabel 6 .

Tabel 6. Sistem Informasi Akademik

\begin{aligned} & \hline No \multicolumn{1}{c}{ SIM dan Aplikasi } \\ & \hline 1 SIM PMB \\ & \hline 2 SIM Pelepasan Mahasiswa \\ & \hline 3 SIM Almuni dan Pusat Karir \\ & \hline 4 SIM Layanan Perpustakaan \\ & \hline 5 SIM Pengabdian Kepada Masyarakat \\ & \hline 6 AP. Web Universitas \\ & \hline 7 AP. Perencanaan Operasional Akademik \\ & \hline 8 AP. Pengelolaan Data Mahasiswa \\ & \hline 9 AP. Pengelolaan data Dosen \\ & \hline 10 AP. Perwalian \\ & \hline 11 AP. Penjadwalan Perkuliahan \\ & \hline 12 AP. Pengelolaan Data Mahasiswa \\ & \hline 13 AP. Evaluasi Perkuliahan \\ & \hline 14 AP. Hasil Studi \\ & \hline 15 AP. E-Learning \\ & \hline 16 AP. Manajemen Tugas Akhir \\ & \hline 17 AP. Cuti Akademik \\ & \hline 18 AP. Pelaporan Akdemik \\ & \hline 19 AP. SMS Center \\ & \hline 20 AP. Evaluasi Perkuliahan \\ & \hline 21 AP. Hasil Studi \\ & \hline \\ & \hline\end{aligned}

E. Arsitektur Teknologi

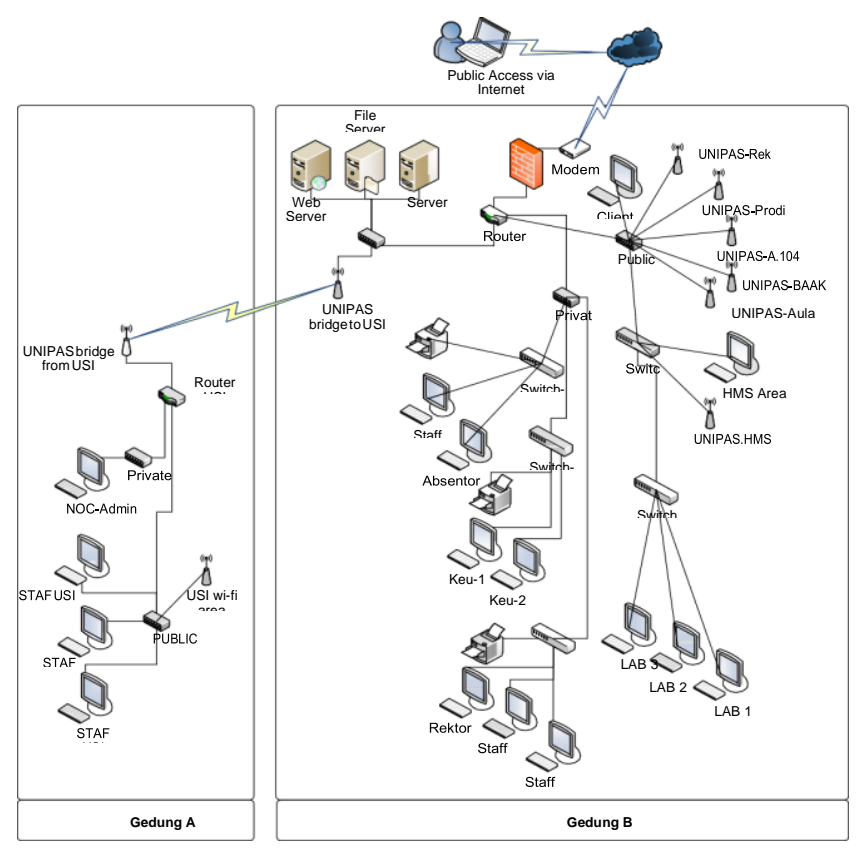

Gambar 4. Konsep Arsitektur Jaringan 
Rancangan pembangunan arsitektur teknologi yang diinginkan dalam rangka untuk mendukung proses bisnis di UNIPAS Morotai, maka model infrastruktur jaringan yang digunakan pada perancangan arsitektur sebagaimana pada Gambar 4, yang merupakan hasil dari analisa kondisi arsitektur teknologi di Universitas Pasifik (UNIPAS) Morotai.

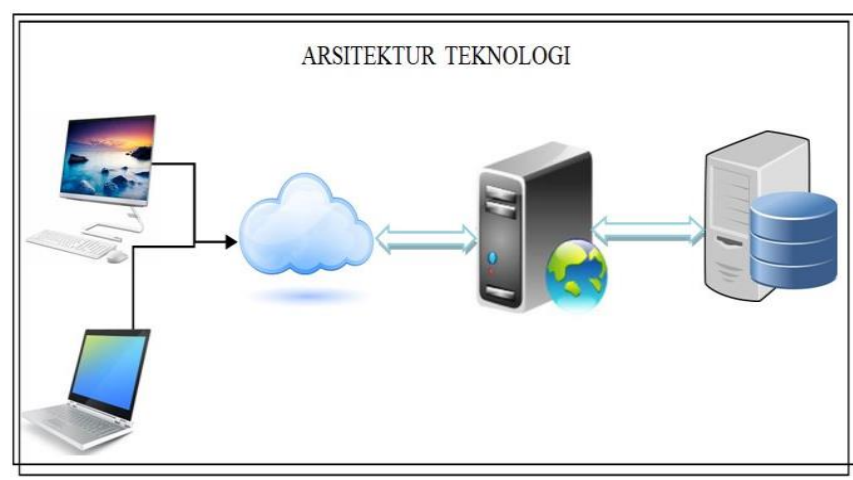

Gambar 5. Cetak Biru (Blueprint) Arsitektur yang Dihasilkan

Berdasarkan hubungan arsitektur, mulai dari arsitektur bisnis, arsitektur aplikasi, arsitektur sistem informasi, dan arsitektur teknologi, maka dapat menghasilkan sebuah platform atau cetak biru (blue print) pada Gambar 5, yang akan dijadikan sebagai acuan atau panduan dalam membangun dan mengembangkan sistem informasi di Universitas Pasifik (UNIPAS) Morotai yang terintegrasi oleh semua unit organisasi.

\section{KESIMPULAN}

Berdasarkan pembahasan yang telah dijelaskan di atas yang sesuai dengan tahapan dan proses penelitian, maka dapat disimpulkan bahwa dengan menggunakan metode TOGAF-ADM yang digunakan sebagai alat (tools) untuk pembuatan dan perancangan arsitektur enterprise pada penelitian ini, telah menghasilkan rancangan model arsitektur secara umum sebagaimana visi dan misi organisasi.

Dari hasil pengelompokan perencanaan sistem informasi dan aplikasi dari 4 (empat) proses aktivitas utama yang terdiri atas Sistem Informasi Penerimaan Mahasiswa Baru (PMB), Operasional Akademik, Pelepasan Mahasiswa serta Alumni dan Pusat Karir, yang akan digunakan sebagai instrumen untuk mendukung pengembangan Perguruan Tinggi.

Universitas Pasifik (UNIPAS) Morotai memiliki harapan, bahwa dengan adanya perencanaan arsitektur enterprise sistem informasi ini, akan menghasilkan perbaikan dalam proses kinerja Layanan Akademik secara kolektif, arsitektur sistem informasi pada semua unit organisasi yang terintegrasi dapat menyelesaikan permasalahan yang dihadapi, data dan informasi yang dibutuhkan akan diproses secara cepat dan tepat, dengan adanya sistem informasi yang terintegrasi.

\section{SARAN}

Penulis menyadari bahwa hasil perancangan arsitektur bisnis dan sistem informasi yang terintegrasi pada Universitas Pasifik (UNIPAS) Morotai ini masih jauh dari harapan dan kesempurnaan. Oleh karena itu penulis mengharapkan akan ada pengembangan yang dilakukan oleh yang lainnya, dengan tampilan dan perancancangan sistem yang lebih baik berdasarkan perkembangan teknologi, untuk mendukung tujuan strategis bisnis pada Universitas Pasifik (UNIPAS) Morotai sebagaimana yang diharapkan.

\section{REFERENSI}

[1] Cretu, L.G. (2016). Designing Enterprise Architecture Frameworks: Integrating Business Processes with IT Infrastructure. Toronto: Apple Academic Press.

[2] Setiawan, R. (2015). Perancangan Arsitektur Enterprise Untuk Perguruan Tinggi Swasta Menggunakan TOGAF ADM. Jurnal Algoritma, Vol. 12(1), pp.548-561.

[3] Nama, G.F., Tristiyanto \& Kurniawan, D. (2018) An Enterprise Architecture Planning for Higher Education Using the Open Group Architecture Framework (Togaf): Case Study University of Lampung. Proceeding of Second International Conference on Informatics and Computing (ICIC) 2017.

[4] Plataniotis, G. (2017). EA Anamnesis - A Conceptual Framework for Enterprise Architecture Rationalization. Ridderkerk, the Netherlands: Ridderprint BV.

[5] Kurniawan, N.B. \& Suhardi (2014). Enterprise Architecture Design for Ensuring Strategic Business IT Alignment (Integrating SAMM with TOGAF 9.1). Proceeding of 2013 Joint International Conference on Rural Information \& Communication Technology and Electric-Vehicle Technology (rICT \& ICeV-T).

[6] Kotusev, S. (2018). TOGAF Version 9.2: What's New? British Computer Society (BCS).

[7] Negara, J.G.P. \& Emanuel, A.W.R. (2019). Enterprise Architecture Design Strategies for UGK Using TOGAF ADM. Proceeding of 1 st Borobudur International Symposium 2019.

[8] Chaczko, Z., Chiu, C., Kohli, A.S. \& Mahadevan, V. (2010). Smart Hospital Management System: An Integration of Enterprise Level Solutions Utilising Open Group Architecture Framework (TOGAF). Proceeding of 2010 3rd International Conference on Computer Science and Information Technology.

[9] Rusli, D. \& Bandung, Y. (2017). Designing an Enterprise Architecture (EA) Based on TOGAF ADM and MIPI. Proceeding of 2017 International Conference of Information Technology and System Innovation (ICITSI).

[10] Gusmao, U.D.F. \& Setyohadi, D.B. (2017). Strategic 
Planning for the Information Development of IPDC (Instituto Profissional De Canossa) Library Using TOGAF Method. Proceeding of 2017 5th International Conference on Cyber and IT Service Management (CITSM).

[11] Levy, M. \& Bui, Q.N. (2019). How Field-Level Institutions Become a Part of Organizations: a Study of Enterprise Architecture as a Tool For Institutional Change. Information and Organization, Vol. 29(4).

[12] Malyzhenkov, P. \& Ivanova, M. (2017). An Enterprise Architecture-Based Approach to the IT-Business
Alignment: An Integration of SAM and TOGAF Framework. Enterprise and Organizational Modeling and Simulation, pp. 159-173.

[13] Cohn, D.L. (2003). Building and Managing Adaptive E-business Solution Infrastructure. Proceeding of IEEE International Conference on E-Commerce.

[14] Andrade, P., Fiorini, B., Murphy, S., Pigueiras, L. \& Santos, M. (2015). Monitoring Evolution at CERN. Journal of Physics: Conference Series, Vol. 664.

[15] UNIPAS. (2016). Renstra Tahun 2016-2020. Morotai: Universitas Pasifik (UNIPAS). 